\title{
Electrophoretic characterization of Aspergillus nidulans strains with chromosomal duplications
}

\author{
Marisa V. de Queiroz ${ }^{1}$, Aline Aparecida Pizzirani-Kleiner ${ }^{2}$ and João Lúcio Azevedo ${ }^{2}$
}

\begin{abstract}
Pulsed-field gel electrophoresis was used to characterize strains of Aspergillus nidulans with a chromosomal duplication Dp(I-II). Morphologically deteriorated and improved variants of these strains were also analyzed. The electrophoretic karyotype demonstrated that in two duplicated strains (A and B) the $4.2 \mathrm{Mb}$ band, which corresponds to chromosome II, was absent and a new band was observed. Hybridization studies using the uapA (chromosome I) and $w \mathrm{~A}$ (chromosome II) genes demonstrated that the new band corresponded to chromosome II plus the duplicated segment of chromosome I. The size of the chromosomal duplication was approximately 1.0 Mb. Analysis of the chromosomal bands of a morphologically improved strain showed that the duplicated segment of chromosome I was completely lost. The morphologically deteriorated variants V9 and V17 had the same karyotype as the duplicated strains. However, the deteriorated variant V5 lost part of chromosome I and had a rearrangement involving chromosome V. This rearrangement may have resulted from the mutagenic treatment used to obtain the genetic markers. Pulsed-field gel electrophoresis was found to be an excellent tool for locating chromosomal rearrangements.
\end{abstract}

\section{INTRODUCTION}

Strains of Aspergillus nidulans with duplicate chromosomal segments are unstable at mitosis (Bainbridge and Roper, 1966). Two strains (A and B) which carry the same chromosomal duplication, $\mathrm{Dp}$ (I-II), have been widely used to study the main features of mitotic instability (Nga and Roper, 1968; Azevedo and Roper, 1970; Azevedo, 1975; Menezes and Azevedo, 1978; Marjefeld and Roper, 1978). Colonies from strains carrying this duplication have reduced growth rates and mainly produce two types of sectors, designated improved and deteriorated. Improved sectors occur frequently and arise from nuclei which have lost a variable part or all of the duplicated segment (Nga and Roper, 1968). Deteriorated sectors are regularly but less frequently found. These sectors were postulated to result from tandem duplications on duplicated segments or from transposition to non-duplicated regions, with the latter showing a reduced degree of instability (Azevedo and Roper, 1970).

In the last decade, $A$. nidulans has been manipulated by recombinant DNA techniques. This fungus has been used for gene cloning, expression and regulation studies (Bowyer et al., 1994; Lee and Adams, 1994). The karyotype of A. nidulans has also been resolved by electrophoresis (Brody and Carbon, 1989). The size of the individual chromosomes was estimated to be $2.9-5.0 \mathrm{Mb}$, with a total size of $31 \mathrm{Mb}$. The development of pulsed-field gel electrophoresis techniques provides new possibilities for studying how chromosomal duplications affect mitotic instability. We used pulsed-field gel electrophoresis to determine the electrophoretic karyotype of $A$. nidulans strains carrying $\mathrm{Dp}(\mathrm{I}-\mathrm{II})$ and variants derived from them.

\section{MATERIAL AND METHODS}

The A. nidulans strains were derived from Glasgow stocks. Strains A and B were derived from a spontaneous duplication strain (Pritchard, 1956; Nga and Roper, 1968). Deteriorated strains (V5, V9 and V17) were isolated as sectors from strains A and B (Azevedo and Roper, 1970). Two non-duplication strains, pabaA1 and MSE (McCully and Forbes, 1965), were used as controls. One improved strain (AM) obtained as a spontaneous yellow sector from strain A was also used. The culture media were solid and liquid minimal medium (MM) as described by Pontecorvo et al. (1953) supplemented with proline, $\mathrm{p}$-aminobenzoic acid, adenine, biotin, riboflavin, nicotinamide, methionine and pyridoxine.

Chromosomal DNA of A. nidulans was prepared according to Brody and Carbon (1989), with some modifications. About $10^{9}$ conidia from each strain were inoculated in $800 \mathrm{ml}$ of supplemented liquid $\mathrm{MM}$ in two-liter flasks. These were incubated for $12-15 \mathrm{~h}$ at $25^{\circ} \mathrm{C}$, with vigorous shaking. Mycelia were harvested by filtration, washed with OM buffer $\left(1.2 \mathrm{M} \mathrm{MgSO}_{4}, 10 \mathrm{mM}\right.$ sodium phosphate, $\mathrm{pH}$ 5.8) and 1-3 $\mathrm{g}$ was then suspended in 10-20 $\mathrm{ml}$ of OM buffer. Then $20-40 \mathrm{mg}$ of lysing enzyme (Sigma) and $10-20 \mathrm{mg}$ of bovine serum albumin were added. To produce protoplasts, a mycelium from each strain was incubated for $2 \mathrm{~h}$ at $30^{\circ} \mathrm{C}$, with gentle swirling. The suspension was filtered through miracloth and $10 \mathrm{ml}$ of filtrate 
containing the protoplasts was transferred to centrifuge tubes and carefully overlaid with $10 \mathrm{ml}$ of ST buffer $(0.6$ $\mathrm{M}$ sorbitol, $10 \mathrm{mM}$ Tris-HCl, $\mathrm{pH}$ 7.0). The tubes were centrifuged at 4,000 $\mathrm{g}$ for $15 \mathrm{~min}$. The banded protoplasts were removed using a bent Pasteur pipette and mixed with an equal volume of $1 \mathrm{M}$ sorbitol, $10 \mathrm{mM}$ Tris- $\mathrm{HCl}, \mathrm{pH} 7.5$ buffer. The protoplasts were pelleted at $4,300 \mathrm{~g}$ for 10 min and washed twice with $5 \mathrm{ml}$ of $1 \mathrm{M}$ sorbitol, $10 \mathrm{mM}$ Tris- $\mathrm{HCl}(\mathrm{pH} 7.5)$ buffer containing $10 \mathrm{mM} \mathrm{CaCl}_{2}$. The pellet was resuspended in GMB buffer (0.125 M EDTA, $\mathrm{pH} 7.5,0.9 \mathrm{M}$ sorbitol) to give a concentration of $10^{8}$ protoplasts $/ \mathrm{ml}$. An equal volume of molten $1.4 \%$ InCert agarose (FMC) in GMB buffer precooled to $42^{\circ} \mathrm{C}$ was added, and the agarose/protoplast mixture was poured into a plug mold and solidified on ice for $10 \mathrm{~min}$. The agarose plugs were immersed in NDS buffer (0.5 M EDTA, $10 \mathrm{mM}$ Tris$\mathrm{HCl}, \mathrm{pH} 9.5,1 \%$ sodium N-lauroylsarcosinate) containing proteinase $\mathrm{K}(1 \mathrm{mg} / \mathrm{ml})$ at $50^{\circ} \mathrm{C}$ for $24 \mathrm{~h}$. The plugs were washed three times in $50 \mathrm{mM}$ EDTA, $\mathrm{pH} 8.0$, at $50^{\circ} \mathrm{C}$ and stored at $4{ }^{\circ} \mathrm{C}$.

Gel electrophoresis was performed using a Bio-Rad contour-clamped homogeneous electric field (CHEF) system at $45 \mathrm{~V}$. The running buffer was $0.5 \mathrm{X}$ TBE or $0.5 \mathrm{X}$ TAE buffer at $14^{\circ} \mathrm{C}$ (Sambrook et al., 1989). The separation was done on agarose gels, as described by Geiser $e t$ al. (1994), using three pulse intervals of $50 \mathrm{~min}, 45 \mathrm{~min}$ and $37 \mathrm{~min}$ with durations of $73 \mathrm{~h}, 18 \mathrm{~h}$ and $73 \mathrm{~h}$, respectively. The gels were stained with ethidium bromide $(1 \mathrm{mg} /$ $\mathrm{ml}$ ) for $30 \mathrm{~min}$ and destained in distilled water for at least $1 \mathrm{~h}$. After destaining, the gels were soaked successively in $0.25 \mathrm{M} \mathrm{HCl}$ (two 15-min periods) and $0.5 \mathrm{M} \mathrm{NaOH}, 1.0$ $\mathrm{M} \mathrm{NaCl}$ (two 30-min periods) at room temperature, followed by neutralization in $1 \mathrm{M}$ ammonium acetate, $20 \mathrm{mM}$ $\mathrm{NaOH}$ (two 30-min periods). Southern transfer was performed as described by Sambrook at al. (1989). The DNA was transferred to a nylon membrane (Hybond-N, Amersham) for $15 \mathrm{~h}$ in $20 \mathrm{X} \mathrm{SSC}$. The fragments containing the genes uapA (Diallinas and Scazzocchio, 1989), wA (Tilburn et al., 1983), pyrG (Oakley et al., 1987) and $h x \mathrm{~A}$ (Glatigny and Scazzocchio, 1995) used as probes in hybridization experiments were p-dCTP labeled according to the manufacturer's instructions (Multiprime DNA labeling system, Amersham).

\section{RESULTS AND DISCUSSION}

Separation of the chromosomes of A. nidulans strains A and B by a pulsed-field electrophoretic technique (CHEF) produced a different electrophoretic karyotype than that described by Brody and Carbon (1989). In both strains, the band corresponding to chromosome II was not present while a new band of approximately $5.2 \mathrm{Mb}$ was observed (Figure 1A, lanes 2 and 3). Classic genetic techniques have shown that strains A and B carry part of chromosome I duplicated and translocated to chromosome II (Nga and Roper, 1968). To locate chromosome II in these
A

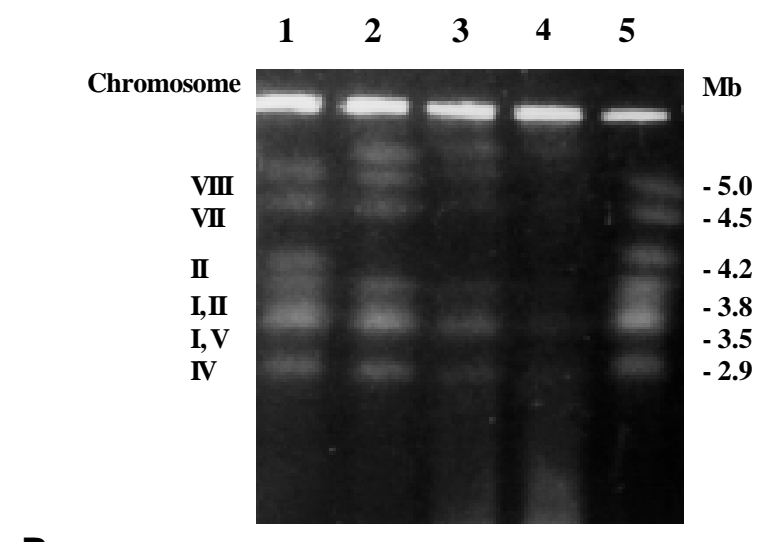

B
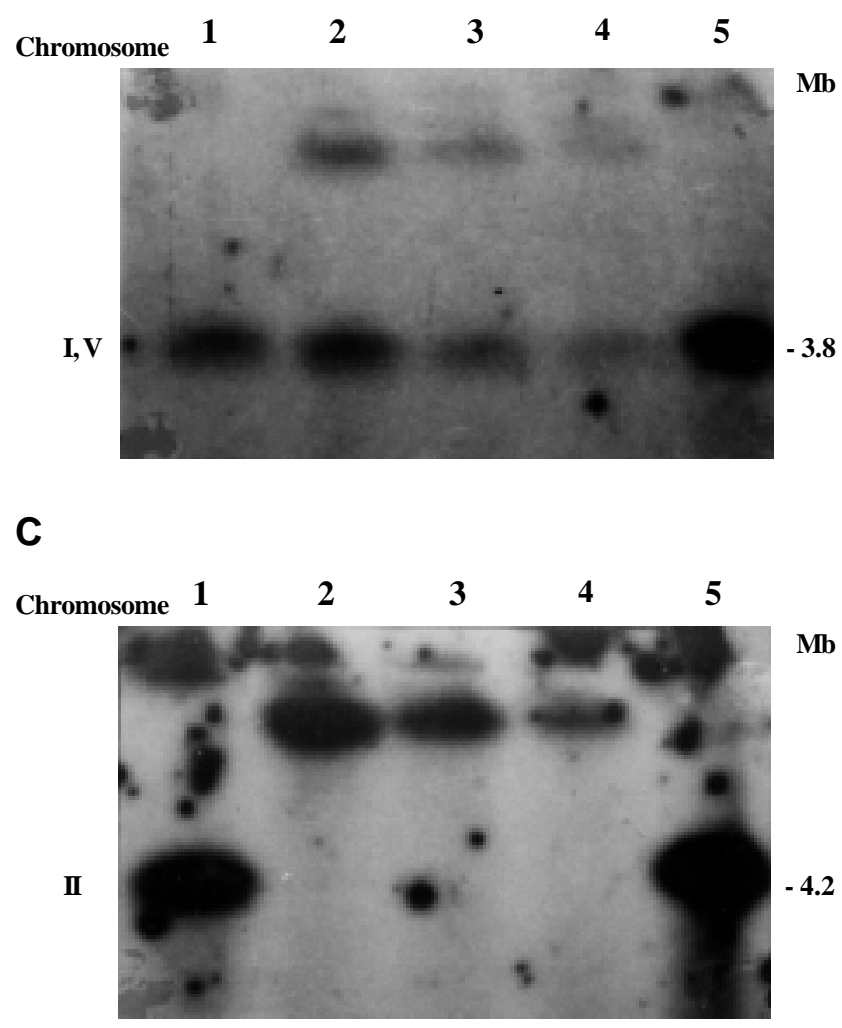

Figure 1 - Separation of Aspergillus nidulans intact chromosomal DNA on a CHEF gel (1A). The DNA was isolated from AM (lane 1), strain A (lane 2), strain B (lane 3), strain V17 (lane 4) and strain pabaA1 (lane 5). B and C, the same DNA samples probed with the labeled genes uap A and $w \mathrm{~A}$, respectively.

strains, the chromosomes were hybridized with gene $w \mathrm{~A}$ of $A$. nidulans. This gene hybridized with the new band of $5.2 \mathrm{Mb}$ in the duplicated strains (Figure 1C, lanes 2, 3 and 4). The chromosomes of the duplicated strains were also hybridized with the uapA gene of $A$. nidulans located in the duplicated portion of chromosome I (Figure 1B). Hybridization of the uapA gene was observed in the band corresponding to chromosome I, as found by Brody and Carbon (1989), as well as in the new 5.2 Mb band. These re- 
sults agree with classic genetic data showing that the 5.2 $\mathrm{Mb}$ band which appears in the duplicated strains represents chromosome II containing part of chromosome I. The size of the duplicated region was approximately $1 \mathrm{Mb}$.

Gene $y \mathrm{~A}$ is found in the duplicated region of strains $\mathrm{A}$ and $\mathrm{B}$. The mutant gene $y \mathrm{~A} 1$ occurs in chromosome I whereas the wild type gene occurs in the duplicated segment of chromosome II. The reverse occurs in strain B. Thus, the duplicated strain A has green conidia and the loss of the duplicated segment linked to chromosome II results in yellow conidia since the wild type gene $y \mathrm{~A}$ is lost. One yellow sector (improved), obtained spontaneously from strain A, had a electrophoretic karyotype similar to that of the control strain pabaA 1 (Figure 1A, B and C, lane 1), indicating that in the improved strain the duplicated segment of chromosome I, which was translocated to chromosome II, was lost so that chromosome II returned to its original size.

Brody and Carbon (1989) examined the electrophoretic karyotype of $A$. nidulans strains with known chromosomal translocations. They performed the hybridization with genetically mapped genes to assign electrophoretic gel bands to specific linkage groups. All translocated strains tested showed alterations in their electrophoretic pattern when compared to non-translocated strains. Geiser et al. (1996) determined the electrophoretic karyotype of $A$. nidulans strains isolated in various parts of the world. One of the isolates (M-85) has a Bchromosome of about $1 \mathrm{Mb}$ and another (Cambridge) a non-reciprocal translocation of about $1.6 \mathrm{Mb}$ from chromosome VI to VIII. Crossing a translocated strain (Cambridge) with a wild type strain produced a variety of phenotypes, including duplicated strains. These authors suggested that the duplicated segment in these strains was more stable than that observed by Bainbridge and Roper (1966) in duplicated strains of A. nidulans, since only one reversible sector was observed in 20 plates analyzed.

Sectors considered deteriorated also appear spontaneously in strains $\mathrm{A}$ and $\mathrm{B}$ of $A$. nidulans. The deteriorated variants have little sporulation and reduced growth compared to the duplicated strains. Azevedo and Roper (1970) suggested that the deteriorated variants could result from tandem duplications in one of the duplicated segments, leading to an increased instability, followed by transposition of this duplication to other genome regions. This suggestion was based on the observation that the factor responsible for the deteriorated phenotype often mapped onto chromosomes which were not involved in chromosomal duplication.

Three deteriorated strains isolated as spontaneous sectors from strains $\mathrm{A}$ and $\mathrm{B}$ of $A$. nidulans by Azevedo and Roper (1970) were analyzed. The mutation responsible for the deteriorated phenotype in both strains was mapped to different chromosomes. The deteriorated variants V5, V9 and V17 had their deteriorated determinants mapped to chromosomes VIII, III and VII, respectively
(Azevedo and Roper, 1970). Variants V9 and V5 were isolated as sectors of strain $\mathrm{A}$ and the variant $\mathrm{V} 17$ as a sector of strain B. Variants V9 (data not shown) and V17 (Figure 1A, lane 4) had the same electrophoretic karyotype as strains A and B. However, variant V5 had a distinct electrophoretic karyotype. Only five chromosomal bands were found in variant V5 (Figure 2A, lane 3). The missing band was characterized by Brody and Carbon (1989) as being formed by chromosomes I and V. The reduction in size of chromosome I in variant V5 may reflect a deletion in the duplicated region present in this chromosome, for this would lead to the loss of approximately $1 \mathrm{Mb}$, causing chromosome I to migrate together with chromosome IV. This, however, does not explain the disappearance of the band corresponding to chromosome $\mathrm{V}$. To locate these two chromosomes (I and V) in variant V5, hybridization was performed with the gene $h x \mathrm{~A}$, present in chromosome $\mathrm{V}$, and with the gene pyr $\mathrm{G}$, present in the non-duplicated region of chromosome I. Chromosome I of strain V5 was confirmed to have a deletion of around $1 \mathrm{Mb}$ and thus migrated together with chromosome IV (Figure 2B, lane 3). Both strains A and V5 have a deletion or translocation of a fragment of chromosome $\mathrm{V}$, causing this chromosome to migrate with chromosomes III and VI (Figure 2C, lane 3). This result was surprising since this rearrangement had not been detected by classic genetic experiments. These findings also confirmed that deletion of the duplicated region in chromosome I was possible, as previously described (Nga and Roper, 1968).

Montenegro et al. (1992) showed that A. nidulans strain ATC 2890 had a rearrangement probably involving duplication of some fragment or translocation. This strain had a larger chromosome III than that observed in other $A$. nidulans strains, which allowed the separation of chromosomes III and VI during electrophoretic karyotyping. These authors have attributed this rearrangement to the ultraviolet irradiation to which this strain was exposed to increase penicillin production. The rearrangement in chromosome $\mathrm{V}$ of strains A and V5 noted in our experiments may also have resulted from the mutagenic treatment used to obtain the genetic markers.

Most of the results obtained in this work confirm and complement data obtained by classic genetic methods. The mechanism responsible for the appearance of spontaneous mutations which produce deteriorated variants and the role chromosomal duplication plays in this process are still unknown. In the three deteriorated strains analyzed, there was no increase in the size of the chromosomes to which mutations responsible for the deteriorated phenotypes have been mapped. Thus, these mutations do not occur by simple translocation of the entire duplicated segment. As shown here and elsewhere (Brody and Carbon, 1989; Montenegro et al., 1992; Zolan, 1995), pulsedfield electrophoresis provides an excellent tool for locating chromosomal rearrangements and can provide data which complement the findings of more classical approaches. 
A

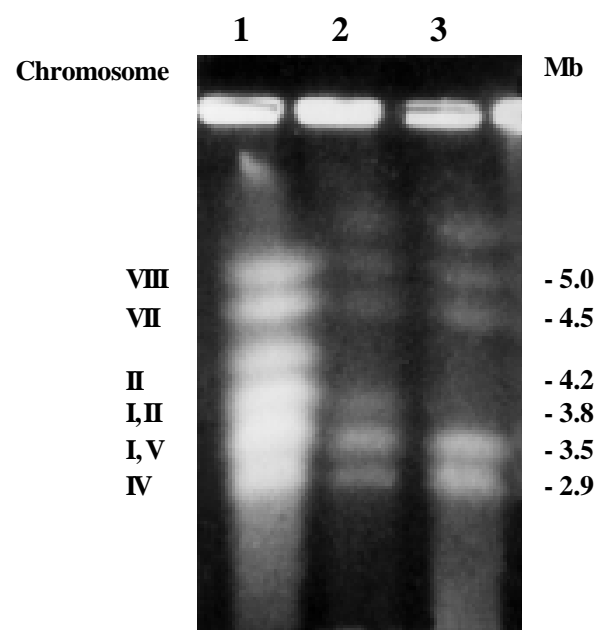

B

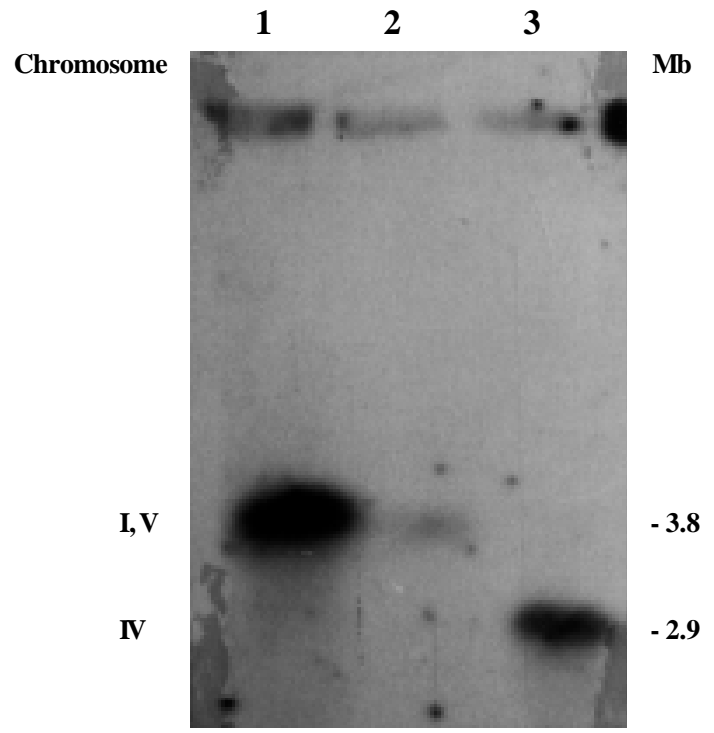

C

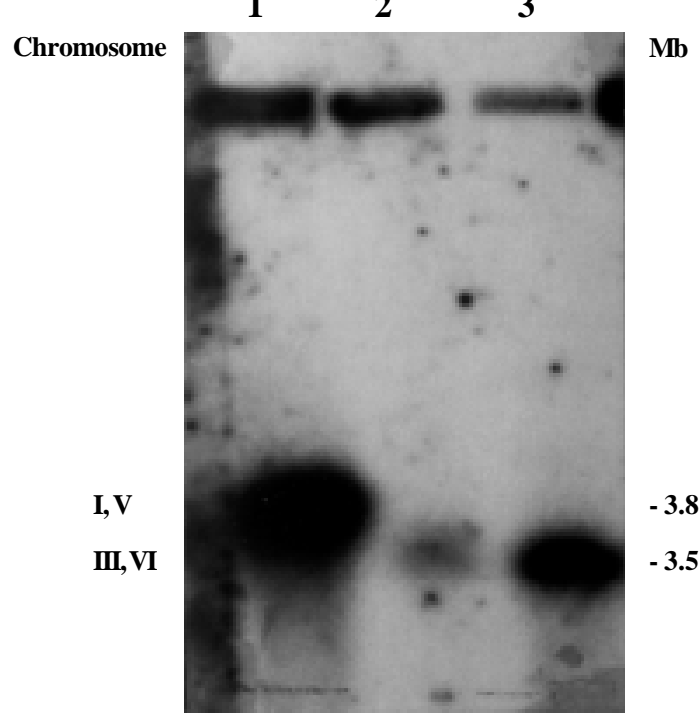

Figure 2 - Separation of Aspergillus nidulans intact chromosomal DNA on a CHEF gel (2A). The DNA was isolated from MSE (lane 1), strain A (lane 2) and strain V5 (lane 3). B and C, the same DNA samples probed with labeled genes pyr $\mathrm{G}$ and $h x \mathrm{~A}$, respectively.

\section{ACKNOWLEDGMENTS}

The authors thank Annie Charbonnier-Glatigny for technical assistance and Professor Claudio Scazzocchio for having received Marisa V. de Queiroz in his laboratory. Marisa V. de Queiroz was supported by a studentship from Conselho Nacional de Desenvolvimento Científico e Tecnológico (CNPq)/RHAE. Publication supported by FAPESP.

\section{RESUMO}

Linhagens de Aspergillus nidulans que apresentam duplicação cromossômica Dp(I-II) foram caracterizadas por eletroforese em campo pulsado. Foram analisados variantes morfologicamente deteriorados e melhorados. O cariótipo eletroforético demonstrou que em ambas as linhagens duplicadas (A e B) a banda de 4,2 $\mathrm{Mb}$, que corresponde ao cromossomo II, não estava presente e foi encontrada uma nova banda. Foram feitas hibridizações usando os genes uapA (cromossomo I) e $w A$ (cromossomo II), que demonstraram que a nova banda corresponde ao cromossomo II mais o segmento duplicado do cromossomo I. O tamanho da duplicação foi determinado como aproximadamente $1,0 \mathrm{Mb}$. A análise das bandas cromossômicas da linhagem morfologicamente melhorada mostrou que o segmento duplicado do cromossomo I foi completamente perdido. Os variantes morfologicamente deteriorados V9 e V17 mostraram o mesmo cariótipo eletroforético apresentado pelas linhagens duplicadas. Contudo, o variante deteriorado V5 perdeu parte do cromossomo I e apresentou um rearranjo envolvendo o cromossomo V. Esse rearranjo pode ter resultado do tratamento mutagênico usado para a obtenção dos marcadores genéticos. Os resultados obtidos nesse trabalho demonstram que a técnica de eletroforese em campo pulsado é uma ferramenta excelente para a localização de rearranjos cromossômicos.

\section{REFERENCES}

Azevedo, J.L. (1975). Altered instability due to genetic changes in a duplication strain of Aspergillus nidulans. Genet. Res. 26: 55-61.

Azevedo, J.L. and Roper, J.A. (1970). Mitotic non-conformity in Aspergillus nidulans: successive and transposable genetic changes. Genet. Res. 16: 79-93.

Bainbridge, B.W. and Roper, J.A. (1966). Observations on the effects of a chromosome duplication in Aspergillus nidulans. J. Gen. Microbiol. 42: 417-424.

Bowyer, P., Osbourn, A.E. and Daniels, M.J. (1994). An "instant gene bank" method for heterologous gene cloning: complementation of two Aspergillus nidulans mutants with Gaeumannomyces graminis DNA. Mol. Gen. Genet. 242: 448-454.

Brody, H. and Carbon, J. (1989). Electrophoretic karyotype of Aspergillus nidulans. Proc. Nat. Acad. Sci. USA 86: 6260-6263.

Diallinas, G. and Scazzocchio, C. (1989). A gene coding for the acid-xanthine permease of Aspergillus nidulans: inactivational cloning, characterization, and sequence of a cis-acting mutation. Genetics 122: 341350.

Geiser, D.M., Arnold, M.L. and Timberlake, W.E. (1994). Sexual origins of British Aspergillus nidulans isolates. Proc. Natl. Acad. Sci. USA 91: 2349-2352

Geiser, D.M., Arnold, M.L. and Timberlake, W.E. (1996). Wild chromosomal variants in Aspergillus nidulans. Curr. Genet. 29: 293-300.

Glatigny, A. and Scazzocchio, C. (1995). Cloning and molecular characterization of hxA, the gene coding for the xanthine dehydrogenase (purine hydroxylase) of Aspergillus nidulans. J. Biol. Chem. 270: 3534-3550.

Lee N.B. and Adams, T.H. (1994). The Aspergillus nidulans fluG gene is 
required for production of an extracellular developmental signal and is related to prokaryotic glutamine synthetase I. Genes Devel. 8: 641-651.

Marjefeld, I.J. and Roper, J.A. (1978). The effects of coumarin on the frequency of deletions in a duplication strain of Aspergillus nidulans. Mol. Gen. Genet. 159: 203-206.

McCully, K.S. and Forbes, E. (1965). The use of p-fluorphenylalanine with "master" strain of Aspergillus nidulans to assign to linkage groups. Genet. Res. 6: 352-359.

Menezes, E.M. and Azevedo, J.L. (1978). Reversion in variant from a duplication strain of Aspergillus nidulans. Mol. Gen. Genet. 164: 255-258.

Montenegro, E., Fierro, F., Fernandez, F.J., Gutiérrez, S. and Martín, J.F. (1992). Resolution of chromosomes III and VI of Aspergillus nidulans by pulsed-field gel electrophoresis shows that the penicillin biosynthetic pathway gene $p c b A B, p c b C$, and $p e n D E$ are clustered on chromosome VI (3.0 megabases). J. Bacteriol. 174: 7063-7067.

Nga, B.H and Roper, J.A. (1968). Quantitative intrachromosomal changes arising at mitosis in Aspergillus nidulans. Genetics 58: 193-209.

Oakley, B.R., Rinehart, J.E., Mitchell, B.L., Oakley, C.E., Carmona, C.,
Gray, G.L. and May, G.S. (1987). Cloning, mapping and molecular analysis of the $\operatorname{pyr} G$ (orotidine-5'-phosphate decarboxylase) gene of Aspergillus nidulans. Gene 61: 385-399.

Pontecorvo, G., Roper, J.A., Hemons, L.M., MacDonald, K.D. and Bufton, A.W.J. (1953). The genetics of Aspergillus nidulans. Adv. Genet. 5: 141-238.

Pritchard, R.H. (1956). A genetic investigation of some adenine-requiring mutants of Aspergillus nidulans. PhD thesis, Glasgow University, UK.

Sambrook, J., Fritsch, E.F. and Maniatis, T. (1989). Molecular Cloning: a Laboratory Manual. Cold Spring Harbor Laboratory Press, New York.

Tilburn, J., Scazzocchio, C., Taylor, G.G., Zabicky-Zissima, J.H., Lockington, R.A. and Davis, R.W. (1983). Transformation by integration in Aspergillus nidulans. Gene 26: 205-221.

Zolan, M.E. (1995). Chromosome-length polymorphism in fungi. Microbiol. Rev. 59: 686-698.

(Received June 29, 1999) 
